\title{
Heterogeneity in Income Tax Capitalization: Evidence from the Swiss Housing Market
}

Mario Morger $^{a}$

JEL-Classification: H22, H73, R21, R38.

Keywords: housing prices, income tax capitalization, segregation

\section{SUMMARY}

There is evidence that taxes capitalize into housing prices, but great uncertainty about the magnitude of income tax capitalization. One explanation why empirical evidence is unclear may stem from the fact that capitalization is something personal, depending on income, mobility, and on the individual tax burden of the bidding households. Therefore, income tax capitalization may theoretically differ substantially between different housing price segments. Results obtained from the analysis of a large Swiss dataset suggest that capitalization is lower for apartments for rent compared to apartments for sale. Capitalization is insignificant or less than $100 \%$ for all rental segments. Concerning apartments for sale, capitalization is well above $100 \%$ for the low and top price segments.

a Centre for Labour and Social Policy Studies BASS and University of Lucerne. Mailing address: Centre for Labour and Social Policy Studies BASS, Konsumstrasse 20, 3007 Berne, Switzerland; +413138060 91; mario.morger@buerobass.ch.

This study was realized during my employment at Swiss Federal Tax Administration. I am grateful to the Cantonal Bank of Zurich, and especially to Marco Salvi (now Avenir Suisse) and Peter Meier, for providing the homegate.ch dataset. I am also indebted to Thomas Brändle, Martin Daepp, Bruno Jeitziner, Alowin Moes, Rudi Peters, Raphaël Parchet, Christoph Schaltegger, Peter Schwarz, David Stadelmann, Philippe Thalmann, Volker Grossmann, two anonymous referees, and the participants of the 2013 meeting of the Swiss Society of Economics and Statistics (SSES) in Neuchatel for helpful discussions and comments. 


\section{Introduction}

According to Tiebout's (1956) "voting with one's feet" theory, fully mobile and well-informed consumers tend to settle in municipalities where their preferred mix of tax and public goods is available. OAtes (1969) has applied Tiebout's model to an analysis of the links between housing prices and property taxes. He hypothesizes that local taxes and local public goods will be reflected in the bid behavior of a fully mobile household interested in buying a house. This means that higher taxes compared to neighborhood regions will lead to lower housing prices. In other words, regional tax differences are capitalized into property values.

In those countries with a federal structure, capitalization of taxes is relevant for politics. First, heterogeneity in income tax capitalization may result in social segregation (Ellickson, 1971; Westhoff, 1977; Goodspeed, 1989; SchmidHEINY, 2006a, 2006b). In Switzerland, there is increasing concern that wealthy people who settle down in low tax regions boost land prices, possibly leading to an emigration of the local population. ${ }^{1}$ Second, because of the social segregation, local redistribution of income becomes more difficult.

Despite this political concern, evidence of the capitalization of income taxes is limited (exceptions are Stull and Stull, 1991; Boije, 1997; Stadelmann and Billon, 2012; Stadelmann and Billon, 2015). To the best of the authors' knowledge, there is no empirical evidence on heterogeneity in income tax capitalization. This study aims to close this knowledge gap by investigating the capitalization rate of income taxes for different apartment price segments in the Swiss housing market.

The dataset utilized in this study in order to investigate heterogeneity in capitalization is from the real estate marketplace homegate.ch; it covers more than 430,000 apartments for rent and sale across Switzerland between 2004 and 2010. Results suggest that capitalization is lower for apartments for rent compared to apartments for sale. Capitalization is insignificant or less than $100 \%$ for all rental segments. Concerning apartments for sale, capitalization is well above $100 \%$ for the low and top price segments.

This paper is organized as follows. Section 2 briefly reviews the existing literature on the determinants and evidence of tax capitalization. The institutional context, the dataset, and the empirical design are described in section 3. Section 4 discusses the study's results, and section 5 provides the conclusions.

1 See, for example, Eichenberger and Stadelmann, Verdrängungskampf im Paradies, Weltwoche, 16 September 2010; Aschwanden, Mit der Zugisierung leben gelernt, Neue Zürcher Zeitung, 8 September 2015. 


\section{Literature on Capitalization}

\subsection{Determinants of Capitalization}

Essentially, two central aspects determine the degree of income tax capitalization: (1) degree of mobility and the related importance of households "voting with their feet" and (2) the ability of municipalities to expand their borders or to substitute agricultural land for urban land.

\subsubsection{The Mobility of Households}

If people are immobile, the Tiebout model fails; in such a scenario, people will not move to places where they can obtain their preferred public-tax mix. This implies that taxes and public goods would not capitalize into housing prices. Thus, a necessary condition for capitalization to occur is the tax mobility of households.

A large body of empirical literature has investigated the impact of differences in local taxes and public goods on migration and choice of residential location. Most of these studies are based on data from the United States. Dowding, John, and BIGgs (1994) have carried out an extensive survey on empirical literature and conclude that local fiscal differentials affect migration. Low-income earners are more attracted by higher welfare payments, while wealthier households react to tax differences.

With respect to Switzerland, early studies investigating the impact of income tax competition on migration have been performed by KIRCHGÄSSNER and POMMerehne (1996) and Feld and Kirchgässner (2001). They conclude that income distribution can be partly explained by fiscal factors. Schaltegger, Somogyi, and Sturm (2011) confirm these results for the Zurich metropoli$\tan$ area.

Schmidheiny (2006b) and Liebig, Puhani, and Sousa-Poza (2007) directly investigate the impact of local income taxes on migration using individual data. They find evidence that rich and highly qualified households are more willing to migrate based on tax incentives than the average household. Morger (2013) finds that income taxes are a significant pull factor for international migration decisions and intra-national migration within Switzerland; however, his results suggest that the relative impact of taxes compared to other locational factors is rather low.

Hence, both international and Swiss studies show some consensus on the existence of the sorting mechanism proposed by Tiebout. Empirical studies indicate, however, that this sorting does not occur independently of income level, and thus results in social segregation. Based on these findings, it is clear that some 
capitalization should occur, but it is not immediately apparent whether mobility is sufficient in order to ensure full capitalization and whether capitalization differs with respect to income.

\subsubsection{The Supply Elasticity of Land and New Municipalities}

If municipalities with a favorable mix of public services and tax level can expand their supply of land as long as new households arrive, then capitalization will not occur over the long run (see Edel and Sclar 1974; Stadelmann and Billon 2012). Conversely, if the supply of land or the borders of a municipality are fixed, capitalization will occur. Migration will take place until the net utility of public goods (the difference between tax bills and the utility derived from the consumption of public goods) is fully offset by higher housing prices.

Different theoretical considerations lead one to conclude that the supply of land is not elastic. First of all, as Ross and YINGer (1999) note, referring to Yinger (1982), Rose-Ackerman (1983), and Crampton (1996), land that is far away from metropolitan regions will not often be used for purposes other than agriculture. In rural regions, there are few or no jobs available and transportation costs are high. Secondly, undeveloped land is scarce in urban regions. Thirdly, it is difficult for the municipalities with the best service-tax packages to expand their borders at the cost of less successful municipalities (YINGER, 1982). In addition, Epple and Romer (1989) have found that, for the United States, the creation of new municipalities is rare due to institutional rules. All these points suggest that the elastic supply of land and new municipalities is unlikely in real cases.

With regard to Switzerland, Stadelmann and Billon (2015) have investigated whether the capitalization of fiscal variables persists or decreases over time. Their results indicate no significant decrease in capitalization during the period of observation, 1998 to 2004. STADELMANN and Billon (2012) find that supply of undeveloped land in a municipality has no impact on the degree of capitalization. Therefore, both studies conclude that the elasticity of land supply in the Zurich metropolitan region is not sufficiently high to reduce capitalization to zero over the long run.

\subsection{Empirical Findings on Degree of Capitalization}

An extensive body of empirical literature on property tax capitalization indicates that there is strong evidence of capitalization. Early studies have been reviewed by YINGER et al. (1988), who conclude that the most sophisticated studies of property tax capitalization yield capitalization rate estimates between $15 \%$ and 
$60 \%$, assuming a discount rate of $3 \%$. A more recent survey by Sirmans, GATZLAFF, and MACPHERSON (2008) demonstrates that in the 20 years of empirical research on property tax capitalization since YINGER et al.'s (1988) study, the range of credible capitalization rates has not narrowed.

Among newer studies, the work of PALmon and SMITH (1998) is particularly worthy of note as these authors simultaneously estimate capitalization rates and net user cost. The authors estimate capitalization rates between $77.5 \%$ and $108 \%$, finding that all values are insignificantly different from full capitalization. Furthermore, their results suggest that net user cost is typically above 3\%, falling closer to $9 \%$, and that this number varies depending on the characteristics of a house.

Few empirical studies have analyzed the degree of capitalization of income taxes. It appears that the first such study is that of STULL and STULL (1991), who investigate income tax capitalization in the Philadelphia Metropolitan Area. By assuming that the lifetime of the housing is infinite and the net user cost is $10 \%$, they obtain a capitalization rate of income taxes that is between $73 \%$ and $81 \%$. STULL and STULL conclude that property and income taxes capitalize into property values to approximately the same extent. Borje (1997) analyzes income tax capitalization in the "travel to work area" of Stockholm. By assuming a net user cost of 3\%, he estimates a capitalization rate between $17 \%$ and $59 \%$.

With regard to Switzerland, Feld and Kirchgässner (1997) and Hilber (1998) have investigated the capitalization rate of differences in local income taxes. Unfortunately, both studies used aggregated indices of local tax burden, in which it is questionable whether the derived capitalization estimator is meaningful. Feld and KirCHGÄSSNER (1997) find capitalization rates between 18\% and 36\% for rented apartments. Hilber's (1998) capitalization rates are substantially higher, at $72 \%$ for rented apartments and up to $236 \%$ for owner-occupied housing and land.

To complement the discussion on income tax capitalization in Switzerland, one has to take note of STADELMANN's (2010) results based on Bayesian model averaging. They suggest that municipal taxes capitalize with a high posterior probability into housing prices.

To sum up, evidence of the capitalization of income taxes into housing prices is limited, and most work in this field is from Switzerland. Moreover, there is no evidence so far, on how different apartment price segments are related to capitalization. Considering this empirical deficiency, this paper addresses the question of heterogeneity in income tax capitalization. 


\section{Empirical Design}

\subsection{Institutional Context}

Switzerland has a federalist structure and relatively strong institutions of direct democracy. On the one hand, people as citizens of municipalities, cantons, and the state can make propositions addressing policy changes through the instrument of popular initiatives. On the other hand, the population can veto political decisions through an optional or mandatory popular referendum (for more details on Swiss political institutions, see, e.g., Feld, Fischer, and KirchgässNER, 2010).

In combination with direct democratic institutions, the federalist structure of Switzerland supports heterogeneous outcomes in the local provision of public goods and the income tax burden: The 26 cantons are fully sovereign in fixing their own tax schedules. ${ }^{2}$ Municipalities (about 2,600 at the end of 2010) can generally apply a multiplier to the cantonal income tax or participate in other ways (e.g., share tax earnings or apply extraordinary schedules). In terms of revenue, the personal income tax is the most important tax in Switzerland, generating 51.4 billion Swiss francs (CHF) (equivalent to $9.0 \%$ of GDP) in 2010. As only a small share of total income tax earnings goes to the federal government, overall income tax rates differ substantially among and within cantons. $47.9 \%$ of personal income tax revenue goes to the cantons, $32.7 \%$ to the municipalities, and only $19.4 \%$ to the federal government.

Competition within and between cantons is responsible for large income tax differences, often between very small distances. A one-earner household with two childen that earns CHF 100,000 must pay 2.6\% income taxes in Walchwil (Canton of Zug), but $11.5 \%$ in Montalchez (Canton of Neuenburg). ${ }^{3}$ For a household with a gross income of CHF 250,000, the lowest statutory tax rate is levied in Wollerau (Canton of Schwyz), at 10.5\%; the highest tax rate, $26.8 \%$, is levied in Montalchez. ${ }^{4}$ However, even within cantons, tax rates differ significantly: on average, the differential between the maximum and minimum tax rate within cantons is 1.8 (4.0) percentage points, among households with gross incomes of CHF 100,000 (CHF 250,000).

2 However, the Federal Supreme Court of Switzerland restricted the autonomy of the cantons by declaring that regressive tax schedules violate the constitution. Furthermore, the tax base is widely harmonized by federal law.

3 Including federal taxes (0.7\%); rates are applicable to taxable income from the year 2010. 


\subsection{Data}

Homegate.ch is one of the biggest and best-known marketplaces for advertising apartments for rent and sale in Switzerland. After excluding duplicates, the raw data for apartments (houses were excluded because they are only seldom for rent), taken for the period from 2004 to 2010, contains 943,856 advertisements. Of these, 760,366 involved apartments for rent and 183,493 involved apartments for sale. Advertisements that did not contain price information, indications of the number of rooms in the apartment, information on year built, or information on surface area were omitted (473,370 observations). Advertisements with non-plausible price information were also not used (2,025 observations). The resulting advertisement data were then paired with tax burden statistics. For the years under investigation, only tax burdens for the 800 biggest municipalities were available (as of 2010, a total of 2,551 municipalities existed). Therefore, only advertisements involving apartments located in one of these 800 municipalities could be reconsidered. After having matched the advertisement data with other municipality-level variables, the final database contained 430,054 objects, namely, 336,121 apartments for rent and 93,933 apartments for sale. ${ }^{5}$

The revised dataset includes information on the following characteristics: code of the municipality where the apartment is located, year built, number of rooms, surface in square meters, average surface per room, and information whether the apartment has a view, a garage, or an elevator. Furthermore, some apartments are classified as being a duplex apartment, attic, penthouse, terrace house, loft, or a furnished apartment. Finally, the dataset includes dummies for the year of advertisement, in order to consider price developments during 2004-2010.

Advertisement data have some shortcomings compared to transaction data. Advertised prices may differ from effective transaction prices in both directions. Deviations may be substantial if the asking price of the advertiser/seller is far away from market conditions (demanders' willingness to pay). However, we believe that there should be no systematic bias in the estimation results. First, the duration of the advertisement is controlled for. If the asking price of the advertiser is higher than the realizable transaction price, the duration of the advertisement should be longer. Duration days should instead be less if the advertisement price is below

4 Including federal taxes of 5.3\%.

5 Reducing the number of control variables by simultaneously increasing the number of observations leads to largely identical results. Robustness checks suggest that it is more important that the model include the full set of control variables than we work with a maximum number of observations. Robustness checks for the baseline model (Table 2) can be obtained on request from the author. 
the transaction price. Therefore, the number of advertised days is of interest as an opportunity to control for the non-observable difference between the advertised price of the apartment and the final sales price. Second, regional or timespecific differences between advertised prices and market prices (for example, due to a regional surplus in supply) are captured with the help of cluster-specific fixed effects and time dummies. With these aspects controlled for, and considering the large dataset, it seems reasonable to assume that working with advertised prices should not bias our capitalization rate.

Table 1 gives further information (summary statistics) on the dataset. About two-thirds of all apartments for rent were built after 1961, but two-thirds of all advertised apartments for sale were built after 1991. Apartments for sale are on average not only much newer, but also bigger: the average number of rooms is 4.3 , and the average surface 121.9 square meters, compared to 3.4 rooms and 85.5 square meters for apartments for rent.

Table 1: Summary Statistics

\begin{tabular}{|c|c|c|c|c|c|c|c|}
\hline \multirow[b]{2}{*}{ variable } & \multicolumn{3}{|c|}{ apartments for rent } & \multicolumn{4}{|c|}{ apartments for sale } \\
\hline & median & mean & s.d. & $\mathrm{N}$ & median & mean & s.d. \\
\hline \multicolumn{8}{|c|}{ Apartment specific variables } \\
\hline $\begin{array}{l}\text { built before } \\
\text { 1901(reference) }\end{array}$ & 41,694 & & & 3,979 & & & \\
\hline built $1901-1910$ & 4,676 & & & 372 & & & \\
\hline built 1911-1920 & 3,122 & & & 307 & & & \\
\hline built 1921-1930 & 5,067 & & & 348 & & & \\
\hline built $1931-1940$ & 6,938 & & & 313 & & & \\
\hline built $1941-1950$ & 7,625 & & & 281 & & & \\
\hline built 1951-1960 & 30,707 & & & 1,010 & & & \\
\hline built $1961-1970$ & 49,167 & & & 4,233 & & & \\
\hline built $1971-1980$ & 39,892 & & & 10,694 & & & \\
\hline built $1981-1990$ & 46,406 & & & 10,584 & & & \\
\hline built 1991-2000 & 42,385 & & & 16,622 & & & \\
\hline built 2001-2005 & 30,243 & & & 13,034 & & & \\
\hline built after 2005 & 28,199 & & & 32,156 & & & \\
\hline
\end{tabular}




\begin{tabular}{|c|c|c|c|c|c|c|c|c|}
\hline \multirow[b]{2}{*}{ variable } & \multicolumn{4}{|c|}{ apartments for rent } & \multicolumn{4}{|c|}{ apartments for sale } \\
\hline & $\mathrm{N}$ & median & mean & s.d. & $\mathrm{N}$ & median & mean & s.d. \\
\hline number of rooms & & 3.5 & 3.4 & 1.2 & & 4.5 & 4.3 & 1.1 \\
\hline surface & & 82.0 & 85.5 & 35.1 & & 119.0 & 121.9 & 42.7 \\
\hline surface per room & & 24.0 & 25.3 & 7.4 & & 27.1 & 28.2 & 7.7 \\
\hline with view & 94,068 & & & & 42,699 & & & \\
\hline with elevator & 141,270 & & & & 61,181 & & & \\
\hline with garage & 142,719 & & & & 60,054 & & & \\
\hline $\begin{array}{l}\text { advertisement duration } \\
\text { in days }\end{array}$ & & 23 & 50 & 79 & & 57 & 113 & 157 \\
\hline duplex apartment & 16,190 & & & & 8,026 & & & \\
\hline attic & 9,716 & & & & 7,221 & & & \\
\hline penthouse & 12,420 & & & & 5,354 & & & \\
\hline furnished & 4,961 & & & & 233 & & & \\
\hline terrace house & 1,400 & & & & 2,897 & & & \\
\hline loft & 1,266 & & & & 541 & & & \\
\hline $\begin{array}{l}\text { other apartments } \\
\text { (reference) }\end{array}$ & 290,168 & & & & 69,661 & & & \\
\hline $\begin{array}{l}\text { year of advertisement: } \\
2004 \text { (reference) }\end{array}$ & 30,010 & & & & 6,103 & & & \\
\hline $\begin{array}{l}\text { year of advertisement: } \\
2005\end{array}$ & 44,033 & & & & 8,379 & & & \\
\hline $\begin{array}{l}\text { year of advertisement: } \\
2006\end{array}$ & 53,546 & & & & 11,267 & & & \\
\hline $\begin{array}{l}\text { year of advertisement: } \\
2007\end{array}$ & 56,946 & & & & 15,695 & & & \\
\hline $\begin{array}{l}\text { year of advertisement: } \\
2008\end{array}$ & 48,264 & & & & 17,246 & & & \\
\hline $\begin{array}{l}\text { year of advertisement: } \\
2009\end{array}$ & 50,226 & & & & 16,863 & & & \\
\hline $\begin{array}{l}\text { year of advertisement: } \\
2010\end{array}$ & 53,096 & & & & 18,380 & & & \\
\hline
\end{tabular}




\begin{tabular}{|c|c|c|c|c|c|c|c|c|}
\hline \multirow[b]{2}{*}{ variable } & \multicolumn{4}{|c|}{ apartments for rent } & \multicolumn{4}{|c|}{ apartments for sale } \\
\hline & $\mathrm{N}$ & median & mean & s.d. & $\mathrm{N}$ & median & mean & s.d. \\
\hline \multicolumn{9}{|c|}{ location specific variables (on municipality level) } \\
\hline $\begin{array}{l}\text { median taxable income in } \\
\mathrm{CHF}\end{array}$ & & 45,400 & 46,817 & 6,300 & & 45,600 & 45,989 & 8,743 \\
\hline $\begin{array}{l}\text { share of employees, } \\
\text { primary sector }\end{array}$ & & 0.005 & 0.015 & 0.027 & & 0.015 & 0.032 & 0.044 \\
\hline $\begin{array}{l}\text { share of empl., secondary } \\
\text { sector }\end{array}$ & & 0.252 & 0.266 & 0.134 & & 0.289 & 0.300 & 0.143 \\
\hline $\begin{array}{l}\text { share of empl., tertiary } \\
\text { sector (ref.) }\end{array}$ & & 0.746 & 0.719 & 0.144 & & 0.683 & 0.668 & 0.155 \\
\hline share secondary residence & & 0.085 & 0.095 & 0.038 & & 0.095 & 0.144 & 0.137 \\
\hline share unbuilt area & & 0.149 & 0.148 & 0.067 & & 0.172 & 0.183 & 0.081 \\
\hline share new construction & & 0.005 & 0.012 & 0.021 & & 0.009 & 0.019 & 0.030 \\
\hline population number & & 17,086 & 79,573 & 117,387 & & 8,432 & 29,836 & 68,864 \\
\hline share population $65+$ & & 0.159 & 0.162 & 0.027 & & 0.158 & 0.160 & 0.033 \\
\hline location: center & 153,196 & & & & 23,828 & & & \\
\hline location: suburb & 130,342 & & & & 34,121 & & & \\
\hline location: peri-urban & 18,153 & & & & 10,463 & & & \\
\hline location: industrial/tertiary & 9,766 & & & & 6,714 & & & \\
\hline location: rural & 3,971 & & & & 3,282 & & & \\
\hline location: touristic & 1,388 & & & & 8,096 & & & \\
\hline $\begin{array}{l}\text { location: wealthy } \\
\text { municipalities (ref.) }\end{array}$ & 19,305 & & & & 7,429 & & & \\
\hline Alps & 36,518 & & & & 29,687 & & & \\
\hline French speaking & 29,925 & & & & 14,804 & & & \\
\hline $\begin{array}{l}\text { German, Italian, Rhaeto- } \\
\text { Romanic (ref.) }\end{array}$ & 306,196 & & & & 79,129 & & & \\
\hline Total & 336,121 & & & & 93,933 & & & \\
\hline
\end{tabular}

Notes: Summary statistics include the number of observations $(\mathrm{N})$ and, except for $0 / 1$ variables, the median, mean and standard deviation (s.d.) of the variables. Location-specific variables do not vary between apartments that are located within the same municipality. 
The matched statistics at the municipality level include: the median taxable income in Swiss Francs (CHF) in the respective year (source: Federal Tax Administration, FTA); the share of full-time employees in the first, second, and third sector (average of 2005 and 2008, SFSO); the share of secondary residences (year 2000 values from the SFSO); the share of residential and mixed-use zones that are undeveloped (year 2007 values, Federal Office for Spatial Development); the proportion of newly constructed apartments with respect to the stock of all apartments (yearly values from the SFSO); the population number; and the share of the population older than 64 years.

Further, urban indicators are included (municipalities are classified as city, suburb, peri-urban, industrial or tertiary orientated, touristic, or rural) ${ }^{6}$, and some dummy variables indicate if the apartments are located in the Alps or in the French-speaking part of the country. Last, the advertisement dataset needs to be matched with income tax statistics. This procedure will be discussed below.

The aim of this work is to focus on the question of whether capitalization rates vary with respect to the price segment of the apartment-or, in other words, whether capitalization differs between luxury housing and frugal housing. To investigate this research question, one needs to know the hypothetical income tax burden for a given apartment. In order to obtain this information, the following three-step procedure needs to be undertaken:

1. categorize apartments into relatively homogeneous groups $k(k=1,2, \ldots, 5)$;

2. define household groups $i(i=1,2, \ldots, 5)$ that are representative as housing demanders for a specific category of apartments; and

3. assign each apartment of a specific category $k$ a representative household group $i$, where $k=i$, to determine the related income which is taxed at the location of the housing.

\subsubsection{Categorizing Apartments into Relatively Homogeneous Groups of Quality}

For each spatial mobility region and year, we calculate the average of the advertised price and rental fee. In a second step, this mean is deducted from the effective number. The obtained mean-centered price (hereafter, residual price) then serves as the basis for ranking. According to this definition, the higher the residual, the higher the apartment price segment in the respective region. As apartment prices/rents substantially depend on the number of rooms in the flat, only flats with at least four rooms are reconsidered for ranking.

6 According to the geographical classifications of the Swiss Federal Statistical Office. Rural and agrarian municipalities are classed together as "rural". 
This procedure has the advantage that the mean-centered variable can be used as the dependent variable in OLS regression. ${ }^{7}$ If one also mean-centers the exogenous variables in the same way, one obtains the within estimator, which is the fixed effects estimator (CAmeron and Trivedi, 2005, p. 704).

According to the residual price/rent, the ranked apartments are grouped into one of the following five percentile ranges: [0;20], $(20 ; 40],(40 ; 60],(60 ; 80]$, and $(80 ; 100]$.

\subsubsection{Define Household Groups}

According to our model, five subpopulation groups represent the Swiss income distribution. These types of households only differ with respect to gross household income and not, for example, with respect to the number of household members. Therefore, preferences differ only between but not within income groups. Group 1 earns a gross income that equals the $20^{\text {th }}$ percentile of the Swiss income distribution. The gross income of group 2 corresponds to the $40^{\text {th }}$ percentile, that of group 3 to the $60^{\text {th }}$ percentile, and that of group 4 to the $80^{\text {th }}$ percentile. Finally, group 5 earns an income which equals the mean gross income of the top 20\%. All values are obtained from the Swiss Household Budget Survey (average values for the years 2006-2008).

\subsubsection{Assigning Each Apartment a Specific Household}

Having defined the household groups that represent specific types of housing demanders and having categorized the apartments into groups of different price segments, the two dimensions are combined. Specifically, we assume that the $[0 ; 20]$ percentile-range apartments are demanded by households earning a gross income that equals the $20^{\text {th }}$ percentile of the overall income distribution, the (20; 40] percentile-range apartments are demanded by households with a gross income that equals the $40^{\text {th }}$ percentile of the overall income distribution, and so on. ${ }^{8}$

7 As the dependent variable should be logarithmized, the variable to logarithmize must not be negative. Therefore, the dependent variable is defined as the difference between the logarithmized actual price/rent and the logarithmized average. Thus, prices/rents are logarithmized first and mean-centered only in the second step.

8 The upper level of the range is chosen as income reference because of the fundamental assumption of the bidding model: The household with the highest willingness to pay gets the award. For the most luxury apartments - the ones that are in the $(80 ; 100]$ percentile class - we assume that the typical interested person has an income which equals the average of this income percentile (due to the fact that high incomes are distributed very unequally and therefore price bids in this whole group should, on average, not be based on the bid of the richest person in Switzerland). 
With a representative housing demander (a one-earner married couple with two children) for every advertised apartment, one knows the potential income tax base for each apartment. Figure 1 shows the distribution of income tax rates for different apartment price segments. As can be seen, for low-price/low-rent apartments, income tax differences are only modest, as most apartments are situated in regions where an annual gross income of $55,320 \mathrm{CHF}$ is taxed between $0 \%$ and $4 \%$. However, tax burden differences are more pronounced in a top price segment. Here, in most cases, owners and renters are taxed in the range of $9 \%$ to $17 \%$.

\subsection{Estimation Model}

Let housing units be indexed by subscripts $i$ and regions by subscripts $r$. The estimation equation is

$$
p_{i r}=c+\alpha \mathbf{x}_{i r}+\gamma \mathbf{z}_{i r}+\beta t_{i r}+g_{r}+\varepsilon_{i r}
$$

where $p_{i r}$ denotes the logarithm of the advertised price for an apartment for rent or sale, $c$ is a constant, $\mathbf{x}_{i r}$ is a vector containing information on the individual characteristics of the housing, $\mathbf{z}_{i r}$ is a vector of location-specific characteristics (at the municipality level), and $t_{i r}$ denotes the tax burden of the potential owner or renter of unit $i$ in region $r$. All these variables enter into the estimation equation linearly. $\alpha, \gamma$, and $\beta$ are the respective unknown parameters. Specifically, $\beta$ is the tax capitalization coefficient, which takes the form of a semi-elasticity measure. $\varepsilon_{i r}$ is the stochastic error term, which is independently distributed across, but not necessarily within, clusters. ${ }^{10}$

Finally, $g_{r}$ is a cluster-specific effect that accounts for all unobservable and region-specific effects. In particular, it includes the influence of local public goods provision on housing prices and rents. This cluster-specific effect is a random variable that captures unobserved regional heterogeneity. As a clustering variable, the spatial mobility region - as defined by the Swiss Federal Statistical Office

9 Several studies suggest that the hedonic price function is not necessarily linear (see HaLVORSEN and Pollakowski, 1981. or the references in Anglin and Gencay, 1995, and Sheppard, 1999). Therefore, the applied log-linear form seems appropriate.

10 Estimation is done by applying the cluster-robust variance-matrix (see CAMERON and TRIVEDI, 2005, p. 834). This variance-matrix places no restriction on heteroscedasticity and correlation within a cluster. 
Figure 1: Distribution of Apartments with Respect to Average Income Tax Rate
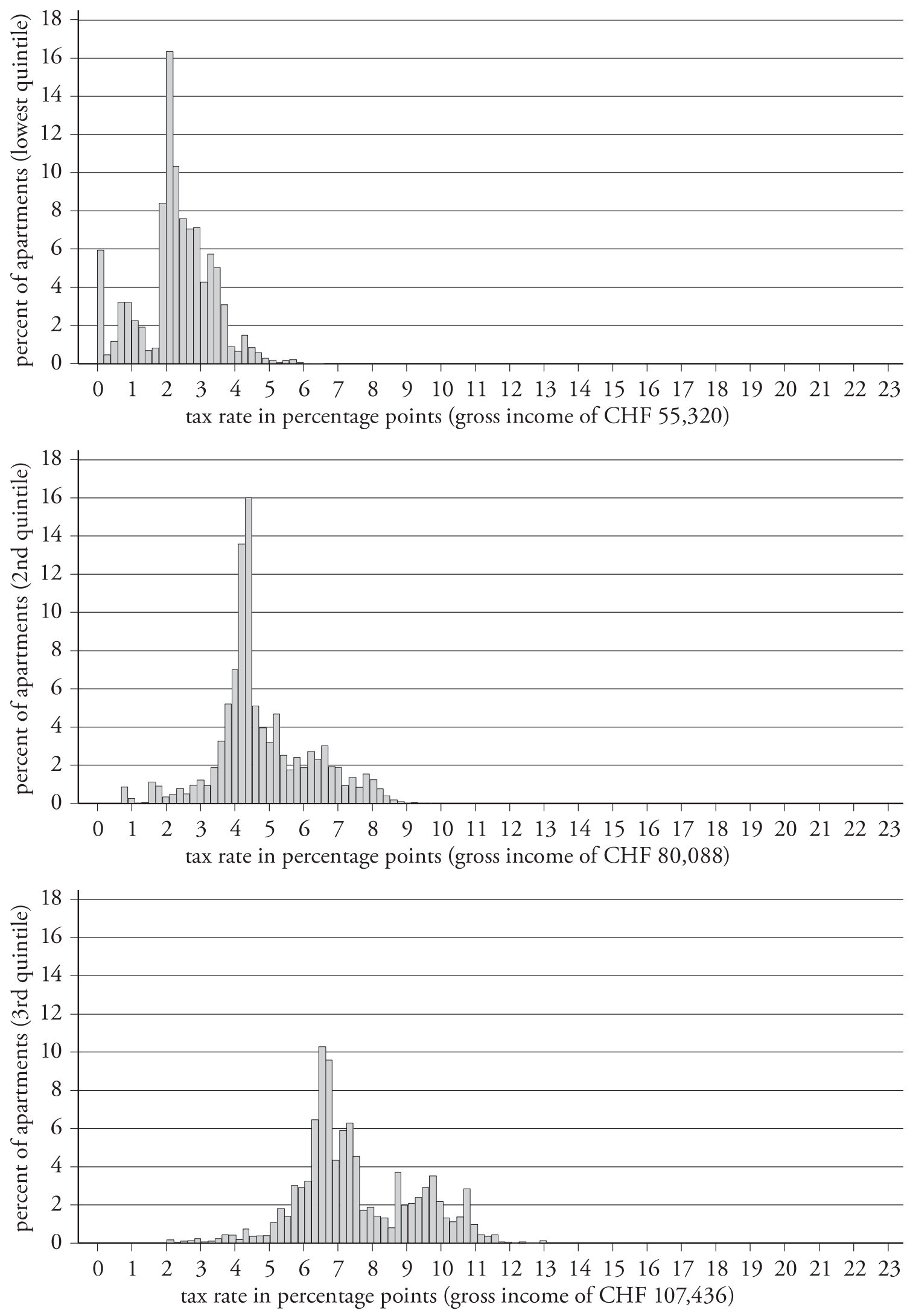

Swiss Journal of Economics and Statistics, 2017, Vol. 153 (3) 

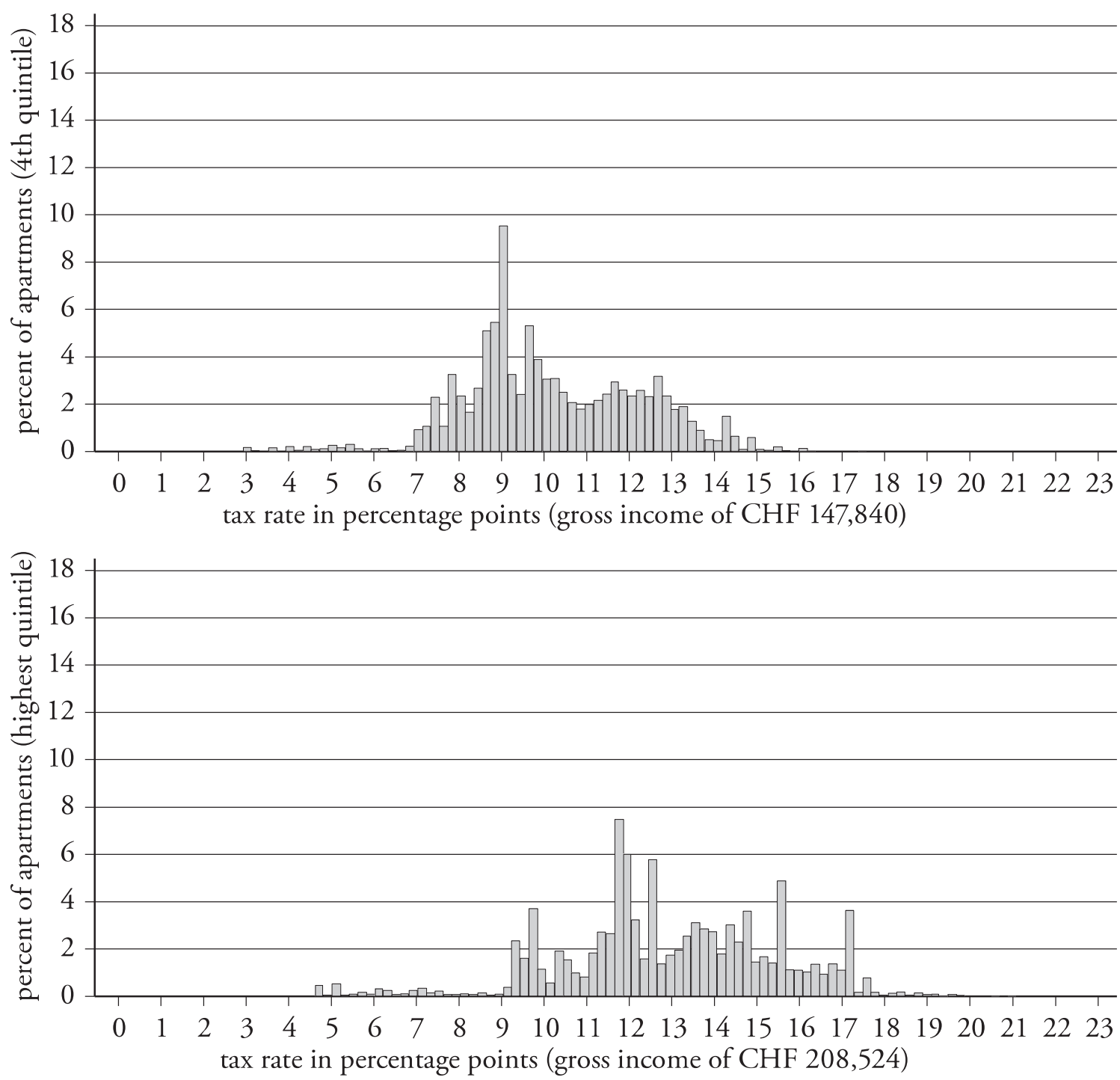

Note: The histograms show the distribution of apartments with respect to the income tax burden of the potential buyer/renter (width of bins: 0.2 percentage points). Income tax burden is measured in percentage points of gross income of a representative household (married, one-earner couple with two children). As the histograms show, the income tax burden is more heterogeneous between potential buyers/renters of apartments in the high price segment (see lower histograms). 
(SFSO) - is chosen. Spatial mobility regions, defined as small job market regions, unite relatively homogeneous neighboring municipalities.

There are two variants of $g_{r}$. In one, it is treated as a random variable that is potentially correlated with the observed regressors. According to this assumption, (1) is the so-called fixed effects model. The fixed effect model allows us to account for any non-observable public goods provision, despite some correlation between public goods provision and the other regressors, such as income taxes. Consistent estimation of the capitalization parameter is made possible. In the other variant, it is treated as a random variable that is not correlated with the regressors. This is the so-called random effects model. The fixed effects model is less efficient than the random effects model if the unobservable cluster effects are purely exogenous. ${ }^{11}$

\section{Results}

\subsection{Fixed vs. Random Effects Model}

To begin with a simple regression model, the control variables and a unique (rather than a simulated apartment-specific) tax rate are applied to the dataset for all flats, including those with less than four rooms. We apply the tax rate of the municipality where the apartment is located to a gross income of CHF 147,840 (the $80^{\text {th }}$ percentile value). This tax base is chosen, because the literature suggests that mainly the wealthy people are tax-sensitive (see section 2.1.1.). Table 2 shows the results for the cluster specific random effects model (CSRE) and the fixed effects (CSFE) model. Standard errors are robust to both arbitrary heteroskedasticity and intra-cluster correlation. As the results show, the coefficients are virtually identical if one compares the fixed and random effects models. However, if one tests for overidentification restrictions (Arellano, 1993; WoOLDRIDGE, 2002), the CSFE model is found to be clearly superior to the CSRE model. From these results, the unobservable cluster effect is correlated with the other regressors. Therefore, we apply only the fixed effects estimator for the following analysis.

11 See, for example, Wooldridge (2002, p. 266) for a discussion of the properties of the fixed effects estimators. 
Table 2: Baseline Regression Results

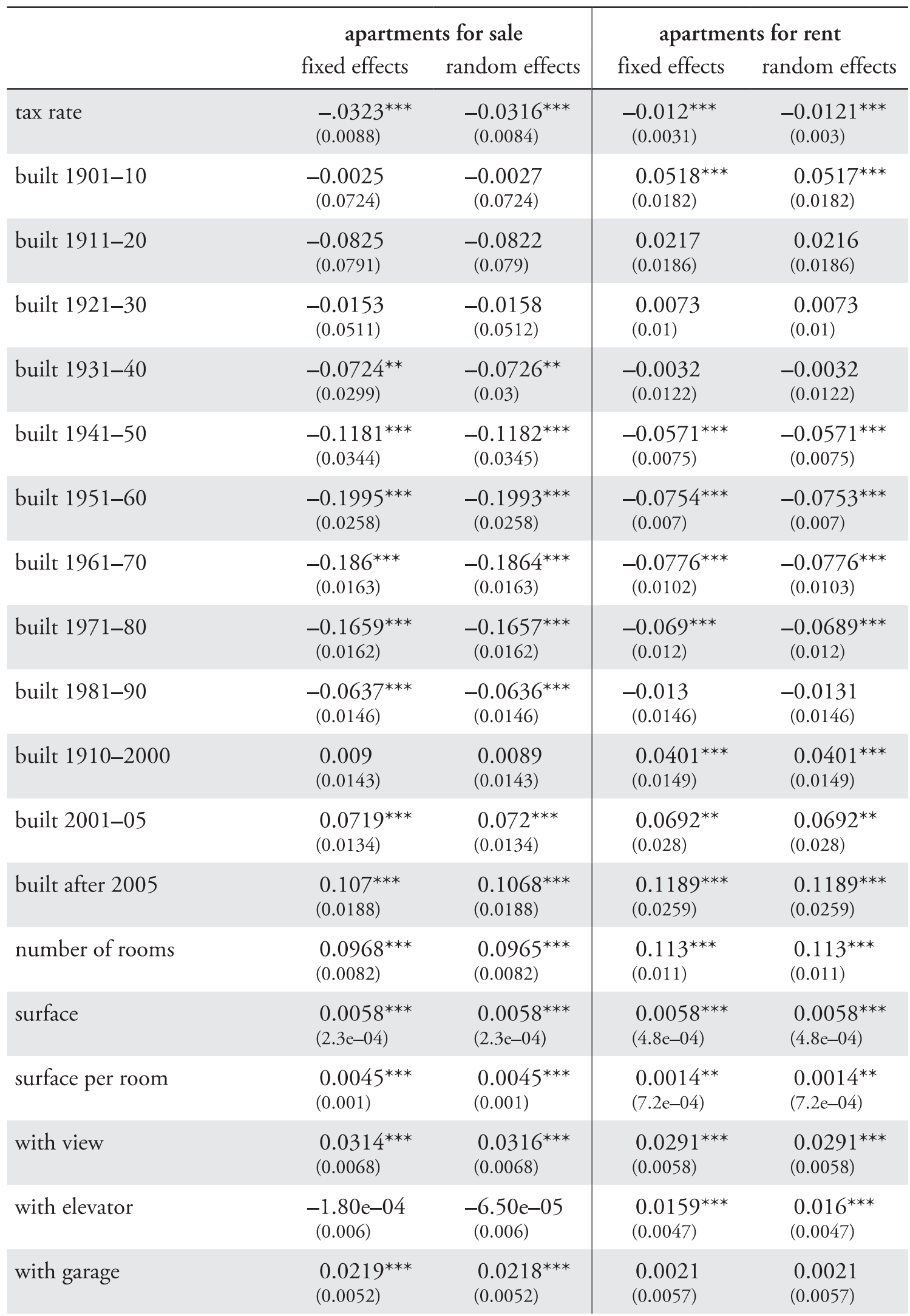




\begin{tabular}{|c|c|c|c|c|}
\hline & \multicolumn{2}{|c|}{ apartments for sale } & \multicolumn{2}{|c|}{ apartments for rent } \\
\hline & fixed effects & random effects & fixed effects & random effects \\
\hline adv. duration & $\begin{array}{l}-7.9 \mathrm{e}-05^{* * *} \\
(1.2 \mathrm{e}-05)\end{array}$ & $\begin{array}{l}-7.9 \mathrm{e}-05^{* * *} \\
(1.2 \mathrm{e}-05)\end{array}$ & $\begin{array}{l}2.0 \mathrm{e}-04^{* * *} \\
(2.8 \mathrm{e}-05)\end{array}$ & $\begin{array}{l}2.0 \mathrm{e}-04^{* * * *} \\
(2.8 \mathrm{e}-05)\end{array}$ \\
\hline duplex & $\begin{array}{l}-0.0292^{* * *} \\
(0.007)\end{array}$ & $\begin{array}{l}-0.0295^{* * *} \\
(0.007)\end{array}$ & $\begin{array}{r}-0.0051 \\
(0.0069)\end{array}$ & $\begin{array}{r}-0.0051 \\
(0.0069)\end{array}$ \\
\hline attic & $\begin{array}{l}0.1828^{* * *} \\
(0.013)\end{array}$ & $\begin{array}{l}0.1827^{* * *} \\
(0.013)\end{array}$ & $\begin{array}{l}0.145^{* * *} \\
(0.0077)\end{array}$ & $\begin{array}{l}0.1451^{* * *} \\
(0.0077)\end{array}$ \\
\hline penthouse & $\begin{array}{l}0.0156^{*} \\
(0.0088)\end{array}$ & $\begin{array}{l}0.0155^{*} \\
(0.0088)\end{array}$ & $\begin{array}{l}0.0525^{* * *} \\
(0.008)\end{array}$ & $\begin{array}{l}0.0525^{* * *} \\
(0.008)\end{array}$ \\
\hline furnished & $\begin{array}{c}-0.0618 \\
(0.039)\end{array}$ & $\begin{array}{c}-0.0622 \\
(0.0391)\end{array}$ & $\begin{array}{l}0.2177^{* * *} \\
(0.0245)\end{array}$ & $\begin{array}{l}0.218^{* * *} \\
(0.0244)\end{array}$ \\
\hline terrace house & $\begin{array}{l}0.1502^{* * *} \\
(0.0147)\end{array}$ & $\begin{array}{l}0.1501^{* * *} \\
(0.0147)\end{array}$ & $\begin{array}{l}0.1424^{* * *} \\
(0.0152)\end{array}$ & $\begin{array}{l}0.1426^{* * *} \\
(0.0152)\end{array}$ \\
\hline loft & $\begin{array}{c}-0.0957^{* * *} \\
(0.0316)\end{array}$ & $\begin{array}{l}-0.0958^{* * *} \\
(0.0316)\end{array}$ & $\begin{array}{l}0.1153^{* * *} \\
(0.0268)\end{array}$ & $\begin{array}{l}0.1154^{* * *} \\
(0.0268)\end{array}$ \\
\hline year 2005 & $\begin{array}{l}0.0045 \\
(0.0085)\end{array}$ & $\begin{array}{l}0.0045 \\
(0.0084)\end{array}$ & $\begin{array}{l}0.002 \\
(0.0024)\end{array}$ & $\begin{array}{l}0.0019 \\
(0.0024)\end{array}$ \\
\hline year 2006 & $\begin{array}{l}0.003 \\
(0.0094)\end{array}$ & $\begin{array}{l}0.0034 \\
(0.0093)\end{array}$ & $\begin{array}{c}-0.0021 \\
(0.0039)\end{array}$ & $\begin{array}{c}-0.0022 \\
(0.004)\end{array}$ \\
\hline year 2007 & $\begin{array}{l}0.0115 \\
(0.0117)\end{array}$ & $\begin{array}{c}0.0117 \\
(0.0116)\end{array}$ & $\begin{array}{l}0.0059 \\
(0.0052)\end{array}$ & $\begin{array}{l}0.0057 \\
(0.0052)\end{array}$ \\
\hline year 2008 & $\begin{array}{l}0.0326^{* *} \\
(0.0159)\end{array}$ & $\begin{array}{l}0.0331^{* *} \\
(0.0157)\end{array}$ & $\begin{array}{l}0.0387^{* * *} \\
(0.0054)\end{array}$ & $\begin{array}{l}0.0384^{* * *} \\
(0.0053)\end{array}$ \\
\hline year 2009 & $\begin{array}{l}0.0617^{* * *} \\
(0.0182)\end{array}$ & $\begin{array}{l}0.0624^{* * *} \\
(0.0179)\end{array}$ & $\begin{array}{l}0.0537^{* * *} \\
(0.0066)\end{array}$ & $\begin{array}{l}0.0533^{* * *} \\
(0.0065)\end{array}$ \\
\hline year 2010 & $\begin{array}{l}0.106^{* * *} \\
(0.0219)\end{array}$ & $\begin{array}{l}0.1068^{* * *} \\
(0.0215)\end{array}$ & $\begin{array}{l}0.0664^{* * *} \\
(0.0077)\end{array}$ & $\begin{array}{l}0.066^{* * *} \\
(0.0076)\end{array}$ \\
\hline median income & $\begin{array}{l}8.6 \mathrm{e}-06^{* * *} \\
(2.0 \mathrm{e}-06)\end{array}$ & $\begin{array}{l}8.7 \mathrm{e}-06^{* * *} \\
(1.9 \mathrm{e}-06)\end{array}$ & $\begin{array}{l}8.5 \mathrm{e}-06^{* * *} \\
(8.3 \mathrm{e}-07)\end{array}$ & $\begin{array}{l}8.5 \mathrm{e}-06^{* * *} \\
(8.2 \mathrm{e}-07)\end{array}$ \\
\hline primary sector & $\begin{array}{c}-0.7845^{* * *} \\
(0.2031)\end{array}$ & $\begin{array}{l}-0.7819^{* * *} \\
(0.2009)\end{array}$ & $\begin{array}{l}-0.6038^{* * *} \\
(0.109)\end{array}$ & $\begin{array}{l}-0.6087^{* * *} \\
(0.1077)\end{array}$ \\
\hline secondary sector & $\begin{array}{l}-0.2247^{* * *} \\
(0.0508)\end{array}$ & $\begin{array}{l}-0.2268^{* * *} \\
(0.0507)\end{array}$ & $\begin{array}{l}-0.1134^{* * *} \\
(0.0271)\end{array}$ & $\begin{array}{l}-0.1157^{* * *} \\
(0.0272)\end{array}$ \\
\hline Sec. residence & $\begin{array}{l}0.9328^{* * *} \\
(0.2591)\end{array}$ & $\begin{array}{l}0.9317^{* * *} \\
(0.2551)\end{array}$ & $\begin{array}{l}0.3485^{* * *} \\
(0.0999)\end{array}$ & $\begin{array}{l}0.3473^{* * *} \\
(0.0945)\end{array}$ \\
\hline unbuilt area & $\begin{array}{c}-0.159 \\
(0.1442)\end{array}$ & $\begin{array}{r}-0.1665 \\
(0.1429)\end{array}$ & $\begin{array}{c}-0.0378 \\
(0.0388)\end{array}$ & $\begin{array}{c}-0.0436 \\
(0.039)\end{array}$ \\
\hline new construction & $\begin{array}{c}-0.1018 \\
(0.069)\end{array}$ & $\begin{array}{c}-0.0996 \\
(0.0692)\end{array}$ & $\begin{array}{l}-0.3252^{* * *} \\
(0.0957)\end{array}$ & $\begin{array}{l}-0.3238^{* * *} \\
(0.0957)\end{array}$ \\
\hline population & $\begin{array}{l}1.6 e-06^{* * *} \\
(3.5 e-07)\end{array}$ & $\begin{array}{l}1.6 \mathrm{e}-06^{* * *} \\
(3.5 \mathrm{e}-07)\end{array}$ & $\begin{array}{l}\text { 7.9e-07*** } \\
(1.1 \mathrm{e}-07)\end{array}$ & $\begin{array}{l}8.1 \mathrm{e}-07^{* * *} \\
(1.1 \mathrm{e}-07)\end{array}$ \\
\hline
\end{tabular}




\begin{tabular}{|c|c|c|c|c|}
\hline & \multicolumn{2}{|c|}{ apartments for sale } & \multicolumn{2}{|c|}{ apartments for rent } \\
\hline & fixed effects & random effects & fixed effects & random effects \\
\hline population $65+$ & $\begin{array}{l}1.005^{* * *} \\
(0.3089)\end{array}$ & $\begin{array}{l}1.001^{* * *} \\
(0.3042)\end{array}$ & $\begin{array}{l}0.3921^{\text {*** }} \\
(0.1072)\end{array}$ & $\begin{array}{l}0.3756^{* * *} \\
(0.1071)\end{array}$ \\
\hline center & $\begin{array}{c}-0.1363^{* * *} \\
(0.0351)\end{array}$ & $\begin{array}{c}-0.1376^{* * *} \\
(0.0351)\end{array}$ & $\begin{array}{c}-0.0459^{*} \\
(0.0261)\end{array}$ & $\begin{array}{c}-0.0469^{*} \\
(0.026)\end{array}$ \\
\hline suburban & $\begin{array}{l}-0.1108^{* * *} \\
(0.029)\end{array}$ & $\begin{array}{l}-0.1107^{* * *} \\
(0.029)\end{array}$ & $\begin{array}{c}-0.0413^{*} \\
(0.0217)\end{array}$ & $\begin{array}{c}-0.0412^{*} \\
(0.0216)\end{array}$ \\
\hline peri-urban & $\begin{array}{c}-0.1063^{* * *} \\
(0.0296)\end{array}$ & $\begin{array}{c}-0.1067^{* * *} \\
(0.0295)\end{array}$ & $\begin{array}{c}-0.0619^{* * * *} \\
(0.0197)\end{array}$ & $\begin{array}{c}-0.0618^{* * *} \\
(0.0197)\end{array}$ \\
\hline industrial/tertiary & $\begin{array}{c}-0.164^{* * *} \\
(0.0326)\end{array}$ & $\begin{array}{c}-0.1657^{* * *} \\
(0.0325)\end{array}$ & $\begin{array}{c}-0.08^{* * *} \\
(0.0238)\end{array}$ & $\begin{array}{c}-0.0809^{* * *} \\
(0.0238)\end{array}$ \\
\hline rural & $\begin{array}{c}-0.1341^{* * *} \\
(0.0334)\end{array}$ & $\begin{array}{c}-0.1346^{* * *} \\
(0.0333)\end{array}$ & $\begin{array}{c}-0.0376^{*} \\
(0.0226)\end{array}$ & $\begin{array}{c}-0.0375^{*} \\
(0.0227)\end{array}$ \\
\hline touristic & $\begin{array}{r}-0.0619 \\
(0.0649)\end{array}$ & $\begin{array}{r}-0.0609 \\
(0.0649)\end{array}$ & $\begin{array}{c}-0.0314 \\
(0.0383)\end{array}$ & $\begin{array}{c}-0.0231 \\
(0.0399)\end{array}$ \\
\hline Alps & $\begin{array}{c}0.0294 \\
(0.0269)\end{array}$ & $\begin{array}{c}0.0282 \\
(0.0262)\end{array}$ & $\begin{array}{c}0.0266 \\
(0.0185)\end{array}$ & $\begin{array}{c}0.0249 \\
(0.0181)\end{array}$ \\
\hline French & $\begin{array}{c}-0.2412^{* * *} \\
(0.0229)\end{array}$ & $\begin{array}{r}-0.0387 \\
(0.0828)\end{array}$ & $\begin{array}{c}-0.1753^{* * *} \\
(0.0109)\end{array}$ & $\begin{array}{c}-0.0637^{*} \\
(0.0362)\end{array}$ \\
\hline constant & $\begin{array}{c}11.81^{* * *} \\
(0.1879)\end{array}$ & $\begin{array}{c}11.72^{* * *} \\
(0.1838)\end{array}$ & $\begin{array}{l}8.568^{* * *} \\
(0.0768)\end{array}$ & $\begin{array}{l}8.508^{* * *} \\
(0.0793)\end{array}$ \\
\hline $\mathrm{R}^{2}$ & 0.721 & & 0.794 & \\
\hline $\mathrm{N}$ & 93,933 & 93,933 & 336,121 & 336,121 \\
\hline
\end{tabular}

Notes: ${ }^{*},{ }^{* *}$, and ${ }^{* * *}$ denote significance at the $10 \%, 5 \%$, and $1 \%$ levels. Dependent variable: logarithm of the rent/price of the apartment. Tax rate: A unique tax rate is applied to the entire dataset (tax rate of the municipality where the apartment is located for a gross income of CHF 147,840). Coefficients are estimated with the help of the Cluster-Specific Fixed Effects Model and the Cluster-Specific Random Effects Model. Standard errors (in parentheses) are robust to both arbitrary heteroscedasticity and intra-cluster correlation. 
The results show that for both rented and owner-occupied apartments, semielasticity is significantly negative. According to the baseline model, an increase in the tax rate by one percentage point, will lead to a reduction in apartment prices of about $3.2 \%$ for owner-occupied apartments and $1.2 \%$ for rented apartments, suggesting that capitalization for apartments for sale is about 2.5 times higher compared to that for apartments for rent. Most apartment-specific factors are statistically highly significant. For example, apartments built between 1931 and 1990 are significantly cheaper than old buildings built before 1901. Instead, new apartments for rent and for sale (built after 2001) are on average 7-12\% more expensive. For any given apartment, the provision of one additional room would lead to an increase in price (rent) of about 10\% (11\%). If an apartment has a view, its price will be approximately $3 \%$ higher than if it had no view.

Furthermore, the estimation results show that the structural features of municipalities can explain differences in rents and prices. In municipalities with a large first or secondary sector, rents and prices are significantly lower than the national average. Prices and rents are higher than average in municipalities with high median incomes, with a high number of inhabitants, or with a high share of older citizens. Urban dummy variables were also found to explain some differences. Time dummy variables show that apartment prices/rents increased steadily after 2004 . In 2010 , prices were about $11 \%$ higher and rents increased about $7 \%$, compared to 2004 . Overall, the models for apartments for sale were able to explain up to $72 \%$ of within-region price heterogeneity; for apartments for rent, the goodness of fit was even higher.

\subsection{Test of Endogeneity}

In order to control for endogeneity, estimations should be repeated with two-stage least squares (2SLS). As income tax instruments, the wealth tax rates are used. This is motivated by two considerations. First, the correlation between these variables is considerable. ${ }^{12}$ Second, the wealth tax rate is likely to have been less endogenous in recent years, as tax competition between municipalities has been much more pronounced for income taxes than for wealth taxes. ${ }^{13}$

12 For example, the correlation between the tax rate for gross family incomes of CHF 147,840 and assets of CHF 500,000 is between 0.67 and 0.74 within the time period 2004-2010 in the 800 largest municipalities.

13 This stylized fact can be seen if one analyzes tax changes between 2004 and 2010 in terms of interquartile range (difference between the $75^{\text {th }}$ and the $25^{\text {th }}$ percentile). Whereas the interquartile range of property tax (assets of CHF 1 million) increased by $47.6 \%$, it decreased 
If one uses the wealth tax rate for assets of CHF 500,000 as instrument, the semi-elasticities are virtually identical to those found for OLS estimates (see Table 3). For apartments for sale, semi-elasticity becomes -0.034 (compared to -0.032 for OLS), and for apartments for rent it becomes -0.007 (compared to -0.012 for OLS). In the first stage, all instruments are significant at the $1 \%$-level. In the second stage, however, the income tax coefficients gets insignificant with respect to apartments for rent. In order to test the quality of the instruments, it is necessary to implement an additional instrument. Otherwise, the model is just identified and the testing of instruments will not be possible. With this in mind, the 2SLS procedure can be repeated, additionally including the wealth tax rate for assets of CHF 100,000. In this case, the tax coefficient remains virtually unchanged $(-0.037$ for apartments for sale and -0.006 for apartments for rent). Furthermore, the overidentification test suggests that the instruments are exogenous. The Hansen-J-statistics give p-values of 0.41 (for apartments for sale) and 0.44 (for apartments for rent), which is highly insignificant. Underidentification test statistics (LM-test) show that the instruments are valid, with p-values below the $1 \%$ level. Finally, the hypothesis of exogeneity cannot be rejected by the $\mathrm{C}$ test (the robust equivalent to the Hausman test), for both apartments for rent and for sale. Due to the clear indication that OLS estimates should not be substantially biased, the following estimates have been based on the OLS method.

\subsection{Robustness Check of Baseline Results}

According to the capitalization literature, it seems important to control for the most important public services at the municipal level. However, reliable data are often not available, and dependence on sporadically accessible expenditure data causes investigators to ignore the inefficiency of provision and the importance of not only the amount but also the quality of public services (for example, the education quality of the local school). For Switzerland, information on the quantity and quality of public goods provided at the local level is nonexistent. Therefore, applying some form of fixed effects or other spatial-clustering in the empirical model is the only possibility to indirectly account for the provision of local public goods.

for income taxes (income of CHF 150,000) by 17.4\%. According to the race-to-the-bottom hypothesis, with increasing tax competition, tax differences should decline over time (as tax burdens converge toward a lower limit). 
Table 3: Estimation Results of 2SLS

\begin{tabular}{|c|c|c|c|c|c|c|c|c|}
\hline \multirow[b]{3}{*}{ variable } & \multicolumn{4}{|c|}{ apartments for sale } & \multicolumn{4}{|c|}{ apartments for rent } \\
\hline & \multicolumn{2}{|c|}{ (1) } & \multicolumn{2}{|c|}{ (2) } & \multicolumn{2}{|c|}{ (3) } & \multicolumn{2}{|c|}{$(4)$} \\
\hline & Coef. & Robust S.E. & Coef. & Robust S.E. & Coef. & Robust S.E. & Coef. & Robust S.E. \\
\hline & \multicolumn{8}{|c|}{ First stage (endogenous variable: tax rate ) } \\
\hline wealth tax (CHF 500,000) & $0.002^{* * *}$ & 0.0002 & $0.002^{* * *}$ & 0.0002 & $0.002^{* * *}$ & 0.0003 & $0.002^{* * *}$ & 0.0003 \\
\hline \multirow[t]{2}{*}{ wealth tax (CHF 100,000) } & - & - & $0.006^{* * *}$ & 0.002 & - & - & $0.005^{* * *}$ & 0.001 \\
\hline & \multicolumn{8}{|c|}{ Second stage (endogenous variable: log of price /rent of advertised apartment) } \\
\hline \multirow[t]{2}{*}{ income tax } & $-0.034^{* *}$ & 0.016 & $-0.037^{* *}$ & 0.017 & -0.007 & 0.004 & -0.006 & 0.004 \\
\hline & \multicolumn{8}{|c|}{ test statistics } \\
\hline underidentification test & & & & & & & & \\
\hline LM statistic & \multicolumn{2}{|c|}{17.51} & \multicolumn{2}{|c|}{22.961} & \multicolumn{2}{|c|}{9.937} & \multicolumn{2}{|c|}{14.882} \\
\hline Chi-sq(1) p-value & \multirow{2}{*}{\multicolumn{2}{|c|}{0.000}} & \multirow{2}{*}{\multicolumn{2}{|c|}{0.000}} & \multirow{2}{*}{\multicolumn{2}{|c|}{0.002}} & \multirow{2}{*}{\multicolumn{2}{|c|}{0.001}} \\
\hline overidentification test & & & & & & & & \\
\hline Hansen J statistic & \multicolumn{2}{|c|}{-} & \multicolumn{2}{|c|}{0.682} & \multicolumn{2}{|c|}{-} & \multicolumn{2}{|c|}{0.599} \\
\hline Chi-sq(1) p-value & & & \multicolumn{2}{|c|}{0.4089} & & & \multicolumn{2}{|c|}{0.4392} \\
\hline \multicolumn{9}{|l|}{ Endogeneity test } \\
\hline C statistic & \multicolumn{2}{|c|}{0.038} & \multicolumn{2}{|c|}{0.001} & \multicolumn{2}{|c|}{2.368} & \multicolumn{2}{|c|}{2.343} \\
\hline Chi-sq(1) p-value & \multicolumn{2}{|c|}{0.8448} & \multicolumn{2}{|c|}{0.9784} & \multicolumn{2}{|c|}{0.1239} & \multicolumn{2}{|c|}{0.1259} \\
\hline
\end{tabular}

Notes: ${ }^{*},{ }^{* *}$, and ${ }^{* * *}$ denote significance at the $10 \%, 5 \%$, and $1 \%$ levels. Fixed effects estimations (clustering at spatial mobility level). Coefficients are estimated with the help of the 2SLS method. Instruments: wealth tax for assets of CHF 500,000 and CHF 100,000. Instrumented: income tax rate (as defined in table 2). Dependent variable: logarithm of the rent/price of the apartment. Estimation and testing were performed with the help of the ivreg2 procedure provided by Baum, Schaffer, and Stillman (2007). 
In the baseline model, two different measures were included to control for unobservable public goods. First, fixed effects at the spatial mobility level were imputed. Second, eight dummies for the different urbanity levels of the municipalities were reconsidered. While a big part of heterogeneity in public goods provision is already considered in this approach, results for the tax variable may still be biased if public service provision varies over time and between municipalities. Therefore, it seems necessary to do some robustness tests to check for possible omitted-variable bias.

First, to reveal the importance of the spatial fixed effects, we repeat the baseline regression [see column (0) of Table 4] by excluding cluster fixed effects [see column (1)]. As a result, the tax coefficient for the subsample of apartments for sale remains almost identical. With respect to apartments for rent, the tax coefficient increases from -0.012 to -0.021 . Next, excluding the urbanity dummies [column (2)] hardly changes the results. Similarly, including 22 urbanity dummies, instead of the 8 broader categories [3], does not change the baseline results.

If local public goods are also available for the non-local population living nearby, the distance to these public goods should matter. Therefore, as the next robustness check, we include an additional variable that signifies the distance of the respective municipality to the next agglomeration center. However, this distance variable is insignificant and has no impact on the tax coefficient [4]. As the next test, a powerful one, we incorporate municipality fixed effects into the model. Now, the tax coefficient becomes totally insignificant [5]. However, this is not surprising as the tax coefficient can now capture only changes in the tax burden within municipalities over time. However, most of this variation is already absorbed by the time dummies. Therefore, if the time dummies are excluded and the regression redone with municipality fixed effects (6), the tax coefficients remain strongly significant at a somewhat higher level compared to the baseline results.

As housing prices substantially increased between 2004 and 2010, it seems important that we incorporate time dummies into the regression model. Therefore, one has to trade off the advantages of including municipality dummies over regional dummies against the disadvantage of excluding time dummies. To reveal the importance of the omitted-variable bias that stems from the excluded time and urbanity dummies, we repeat model (6) with fixed effects at the spatial mobility level [see column (7)]. Then, model (7) can be compared with the baseline results. Omitted-variable bias is shown to be substantial. The income tax coefficients increase substantially. Comparing the baseline model with models (6) and (7), suggests that bias would be greater from non-inclusion of the time dummy than from relying on regional fixed effects instead of municipality fixed effects. 
Table 4: Robustness Tests of Baseline Results

\begin{tabular}{|c|c|c|c|c|c|c|c|c|}
\hline & $(0)$ & (1) & $(2)$ & (3) & $(4)$ & (5) & (6) & (7) \\
\hline \multicolumn{9}{|l|}{ apartments for sale } \\
\hline tax rate & $\begin{array}{c}-0.0323^{* * *} \\
(0.00876)\end{array}$ & $\begin{array}{c}-0.0314^{* * *} \\
(0.00620)\end{array}$ & $\begin{array}{c}-0.035^{* * *} \\
(0.00896)\end{array}$ & $\begin{array}{c}-0.0335^{* * *} \\
(0.00889)\end{array}$ & $\begin{array}{c}-0.0322^{* * *} \\
(0.00866)\end{array}$ & $\begin{array}{r}-0.00052 \\
(0.00584)\end{array}$ & $\begin{array}{c}-0.0487^{* * *} \\
(0.00509)\end{array}$ & $\begin{array}{c}-0.061^{* * *} \\
(0.00759)\end{array}$ \\
\hline distance to next centre & & & & & $\begin{array}{c}-1.20 \mathrm{E}-06 \\
(2.0 \mathrm{E}-06)\end{array}$ & & & \\
\hline $\mathrm{R}^{2}$ & 0.7210 & 0.7415 & 0.7186 & 0.7232 & 0.7210 & 0.7114 & 0.7058 & 0.7154 \\
\hline $\mathrm{N}$ & 93,933 & 93,933 & 93,933 & 93,933 & 93,687 & 93,933 & 93,933 & 93,933 \\
\hline \multicolumn{9}{|l|}{ apartments for rent } \\
\hline tax rate & $\begin{array}{r}-0.012^{* * *} \\
(0.00308)\end{array}$ & $\begin{array}{c}-0.0206^{* * *} \\
(0.00431)\end{array}$ & $\begin{array}{r}-0.013^{* * *} \\
(0.00299)\end{array}$ & $\begin{array}{c}-0.0125^{* * *} \\
(0.00299)\end{array}$ & $\begin{array}{c}-0.0123^{* * *} \\
(0.00298)\end{array}$ & $\begin{array}{l}-0.0052 \\
(0.00391)\end{array}$ & $\begin{array}{c}-0.0266^{* * *} \\
(0.00277)\end{array}$ & $\begin{array}{c}-0.0335^{* * *} \\
(0.00271)\end{array}$ \\
\hline distance to next centre & & & & & $\begin{array}{r}6.10 \mathrm{E}-07 \\
(-7.8 \mathrm{E}-07)\end{array}$ & & & \\
\hline$R^{2}$ & 0.7944 & 0.8113 & 0.7939 & 0.7946 & 0.7944 & 0.7881 & 0.7862 & 0.7915 \\
\hline$N$ & 336,121 & 336,121 & 336,121 & 336,121 & 335,115 & 336,121 & 336,121 & 336,121 \\
\hline \multicolumn{9}{|l|}{ controlled for } \\
\hline fixed effects at spatial mobility region & $\checkmark$ & & $\checkmark$ & $\checkmark$ & $\checkmark$ & & & $\checkmark$ \\
\hline fixed effects at municipality level & & & & & & $\checkmark$ & $\checkmark$ & \\
\hline time fixed effects & $\checkmark$ & $\checkmark$ & $\checkmark$ & $\checkmark$ & $\checkmark$ & $\checkmark$ & & \\
\hline 8 urbanity dummies & $\checkmark$ & $\checkmark$ & & & $\checkmark$ & $\checkmark$ & & \\
\hline 22 urbanity dummies & & & & $\checkmark$ & & & & \\
\hline
\end{tabular}

Notes: ${ }^{*}, * *$, and ${ }^{* *}$ denote significance at the $10 \%, 5 \%$, and $1 \%$ levels. Dependent variable: logarithmized rent/price of the apartment. Tax rate as defined in table 2. Model (0) is the baseline model (see table 2). Standard errors (in parentheses) are robust to both arbitrary heteroscedasticity and intra-cluster correlation. Regression coefficients of control variables are not shown. 
Overall, the robustness checks suggest that the problem concerning omittedvariable bias is not important. It seems that the 106 spatial mobility regions of Switzerland are successful in controlling for local public goods provision. This is not surprising because these spatial mobility regions are in most cases geographically small and are homogeneous regions. Furthermore, important local goods are concentrated at a more aggregated level than the municipality level (high school, hospital) or are even open to the whole Swiss population (museum, theater, universities, public transports, etc.).

\subsection{Heterogeneity in Income Tax Capitalization}

As this paper aims to investigate whether capitalization rates differ in terms of the price segment of housing, we now investigate separately each group of housing and apply the simulated tax rates, as discussed in section 3.2. As the primary interest is to obtain capitalization rates, rather than semi-elasticities, it is necessary to retransform the estimated tax coefficients. Table 5 shows an equivalence scale that allows for the direct retransformation of semi-elasticity measures into capitalization rates. A semi-elasticity value of -0.031 for the lowest $20 \%$ ranked apartments is equal to a capitalization rate of $100 \%$. With respect to the top $20 \%$ ranked apartments, capitalization is full if the semi-elasticity amounts to -0.0516 . A lower (higher) absolute semi-elasticity value means that taxes are only partially (more than fully) capitalized into housing prices.

Now, for each of the five classes of apartments, regressions are separately run. The logarithmized and mean-centered prices are regressed on the control variables (as in the baseline model) and a tax variable (all mean-centered). Table 6 shows the semi-elasticity measures for these different price segments and for different model specifications. Model (1) starts with a simple OLS (within) regression. Because the overall dataset is divided into five different subsamples, the price variable is truncated from above and below, and this model should lead to inconsistent results. Therefore, in model (2), the estimates are repeated with the help of the truncated regression model. ${ }^{14}$ Next, in model (3), all apartments with at least 100 square meters are included (instead of the criterion that the apartments have at least four rooms). The assignment of specific tax rates on the different price segments discussed in section 3.2 is somewhat artificial. Therefore, in model (4a), the top income tax rate (CHF 1 million) is applied for a couple with two children, instead of the specific tax rate. Last, in model (4b), the top income

14 For more details on the truncated regression model, see, for example, Greene (2008, pp. 863-869).

Swiss Journal of Economics and Statistics, 2017, Vol. 153 (3) 
Table 5: Conversion of Semi-Elasticity Measures into Capitalization Rate

\begin{tabular}{lccc}
\hline $\begin{array}{l}\text { price segment } \\
\text { of apartment }\end{array}$ & gross income $\left(y_{i}\right)$ & $\begin{array}{c}\text { Average yearly rental fee } \\
\text { in CHF }\left(p_{i}\right)\end{array}$ & $\begin{array}{c}\text { semi-elasticity of full } \\
\text { capitalization }\end{array}$ \\
\hline$[0 ; 20]$ & 55,320 & 17,872 & -0.0310 \\
$(20 ; 40]$ & 80,088 & 20,612 & -0.0389 \\
$(40 ; 60]$ & 107,436 & 23,142 & -0.0464 \\
$(60 ; 80]$ & 147,840 & 26,748 & -0.0553 \\
$(80 ; 100]$ & 208,524 & 40,409 & -0.0516 \\
\hline
\end{tabular}

Notes: Full capitalization is realized if the change of the apartment rent, $\Delta p i$, in response to a tax rate change equals $-\Delta\left[\mathrm{t}(y)_{i}\right] y_{i}$. Therefore, under full capitalization,

$$
\Delta p_{i}=-\Delta\left[\mathrm{t}(y)_{i}\right] y_{i} .
$$

According to equation (1), $b$ is the estimate of semi-elasticity $\beta$ (in our dataset we specified the tax rate in percentage terms, meaning that it is multiplied by 100$)$ :

$$
b=\frac{\Delta \ln p_{i}}{\Delta\left[t(y)_{i}\right] 100}=\frac{\Delta p_{i} / p_{i}}{\Delta\left[t(y)_{i}\right] 100} .
$$

With (a) inserted into (b), semi-elasticity equals full capitalization if

$$
b_{\text {full cap. }}=-\frac{y_{i}}{p_{i} 100}
$$

Example: In the lowest income percentile,

$$
b_{\text {full cap. }}=-\frac{55,320}{17,872 * 100}=-0.0310 .
$$

\begin{tabular}{|c|c|c|c|c|c|c|}
\hline & {$[0 ; 20]$} & $(20 ; 40]$ & $(40 ; 60]$ & $(60 ; 80]$ & $(20 ; 80]$ & $(80 ; 100]$ \\
\hline \multicolumn{7}{|c|}{ (1) OLS (within estimator) } \\
\hline $\begin{array}{l}\text { coef. } \\
\text { sd } \\
\mathrm{N}\end{array}$ & $\begin{array}{c}-0.0073 \\
(0.0067951) \\
40,657\end{array}$ & $\begin{array}{r}-0.0029 \\
(0.00182) \\
40,660\end{array}$ & $\begin{array}{c}-0.0032^{*} \\
(0.0016217) \\
40,653\end{array}$ & $\begin{array}{c}-0.0056^{* * *} \\
(0.0014487) \\
40,658\end{array}$ & $\begin{array}{c}-0.0217^{* * *} \\
(0.0053503) \\
121,971\end{array}$ & $\begin{array}{r}-0.0075 \\
(0.00681) \\
40,655\end{array}$ \\
\hline \multicolumn{7}{|c|}{ (2) Truncated Regression } \\
\hline $\begin{array}{l}\text { coef. } \\
\text { sd } \\
\mathrm{N}\end{array}$ & $\begin{array}{c}-0.0127 \\
(0.0225231) \\
40,656\end{array}$ & $\begin{array}{c}-0.0199 \\
(0.012364) \\
40,652\end{array}$ & $\begin{array}{c}-0.026^{*} \\
(0.0142356) \\
40,652\end{array}$ & $\begin{array}{c}-0.0403^{* * *} \\
(0.0121147) \\
40,655\end{array}$ & $\begin{array}{c}-0.0374^{* * *} \\
(0.0098061) \\
121,968\end{array}$ & $\begin{array}{r}-0.0218 \\
(0.02439) \\
40,655\end{array}$ \\
\hline
\end{tabular}

Table 6: Capitalization for Different Apartment Price Segments

a) Apartments for rent 


\begin{tabular}{|c|c|c|c|c|c|c|}
\hline & {$[0 ; 20]$} & $(20 ; 40]$ & $(40 ; 60]$ & $(60 ; 80]$ & $(20 ; 80]$ & $(80 ; 100]$ \\
\hline \multicolumn{7}{|c|}{ (3) Truncated Regression, apartments with surface $\geq 100 \mathrm{~m}^{2}$} \\
\hline $\begin{array}{l}\text { coef. } \\
\text { sd } \\
\mathrm{N}\end{array}$ & $\begin{array}{c}-0.0074 \\
(0.07739) \\
21,323\end{array}$ & $\begin{array}{c}-0.0509^{* *} \\
(0.02410) \\
21,322\end{array}$ & $\begin{array}{r}-0.0664^{*} \\
(0.03705) \\
21,321\end{array}$ & $\begin{array}{r}-0.1318^{*} \\
(0.07272) \\
21,320\end{array}$ & $\begin{array}{c}-0.0521^{* * *} \\
(0.0137) \\
63,966\end{array}$ & $\begin{array}{c}0.0047 \\
(0.03375) \\
21,321\end{array}$ \\
\hline \multicolumn{7}{|c|}{ (4a) Truncated Regression, top income tax rate (CHF 1 million) } \\
\hline $\begin{array}{l}\text { coef. } \\
\text { sd } \\
\text { N }\end{array}$ & $\begin{array}{r}-0.0092 \\
(0.01174) \\
40,656\end{array}$ & $\begin{array}{r}-0.0083^{*} \\
(0.00436) \\
40,652\end{array}$ & $\begin{array}{c}-0.0058 \\
(0.00547) \\
40,652\end{array}$ & $\begin{array}{c}-0.0154^{* * *} \\
(0.00546) \\
40,655\end{array}$ & $\begin{array}{c}-0.0111^{* * *} \\
(0.0040) \\
121,968\end{array}$ & $\begin{array}{c}-0.0056 \\
(0.01549) \\
40,655\end{array}$ \\
\hline (4b) Terciles & & {$[0 ; 33.3]$} & & $(33.3 ; 66.6]$ & & $(66.6 ; 100]$ \\
\hline $\begin{array}{l}\text { coef. } \\
\text { sd } \\
\mathrm{N}\end{array}$ & & $\begin{array}{c}-0.0131^{* *} \\
(0.00546) \\
67,760\end{array}$ & & $\begin{array}{c}-0.0109^{* *} \\
(0.00496) \\
67,760\end{array}$ & & $\begin{array}{r}-0.0132 \\
(0.01046) \\
67,756\end{array}$ \\
\hline
\end{tabular}

b) Apartments for sale

\begin{tabular}{|c|c|c|c|c|c|c|}
\hline & {$[0 ; 20]$} & $(20 ; 40]$ & $(40 ; 60]$ & $(60 ; 80]$ & $(20 ; 80]$ & $(80 ; 100]$ \\
\hline \multicolumn{7}{|c|}{ (1) FE-Regression } \\
\hline $\begin{array}{l}\text { coef. } \\
\text { sd } \\
\mathrm{N}\end{array}$ & $\begin{array}{c}-0.0355^{* *} \\
(0.013923) \\
16,528\end{array}$ & $\begin{array}{r}-0.0045 \\
(0.00363) \\
16,524\end{array}$ & $\begin{array}{c}-0.0055^{* * *} \\
(0.00197) \\
16,527\end{array}$ & $\begin{array}{c}-0.0093^{* * *} \\
(0.00231) \\
16,525\end{array}$ & $\begin{array}{c}-0.0346^{* * *} \\
(0.00717) \\
49,576\end{array}$ & $\begin{array}{c}-0.0594^{* * *} \\
(0.0160) \\
16,524\end{array}$ \\
\hline \multicolumn{7}{|c|}{ (2) Truncated Regression } \\
\hline $\begin{array}{l}\text { coef. } \\
\text { sd } \\
\mathrm{N}\end{array}$ & $\begin{array}{c}-0.0894^{* * *} \\
(0.03198) \\
16,523\end{array}$ & $\begin{array}{c}-0.0414 \\
(0.0352249) \\
16,522\end{array}$ & $\begin{array}{c}-0.0517^{* *} \\
(0.0211926) \\
16,520\end{array}$ & $\begin{array}{c}-0.0765^{* * *} \\
(0.0288397) \\
16,522\end{array}$ & $\begin{array}{c}-0.0619^{* * *} \\
(0.0137492) \\
49,573\end{array}$ & $\begin{array}{c}-0.174^{* * *} \\
(0.03556) \\
16,524\end{array}$ \\
\hline \multicolumn{7}{|c|}{ (3) Truncated Regression, apartments with surface $\geq 100 \mathrm{~m}^{2}$} \\
\hline $\begin{array}{l}\text { coef. } \\
\text { sd } \\
\mathrm{N}\end{array}$ & $\begin{array}{c}-0.153^{* * *} \\
(0.0411) \\
13,409\end{array}$ & $\begin{array}{c}-0.0787^{* *} \\
(0.0361) \\
13,399\end{array}$ & $\begin{array}{r}-0.0119 \\
(0.0286) \\
13,400\end{array}$ & $\begin{array}{r}-0.1436 \\
(0.1017) \\
13,407\end{array}$ & $\begin{array}{c}-0.0673^{* * *} \\
(0.0141) \\
40,226\end{array}$ & $\begin{array}{c}-0.186^{* * *} \\
(0.04144) \\
13,406\end{array}$ \\
\hline \multicolumn{7}{|c|}{ (4a) Truncated Regression, top income tax rate (CHF 1 million) } \\
\hline $\begin{array}{l}\text { coef. } \\
\text { sd } \\
\mathrm{N}\end{array}$ & $\begin{array}{c}-0.0397^{* * *} \\
(0.0089) \\
16,523\end{array}$ & $\begin{array}{r}-0.0173^{*} \\
(0.00918) \\
16,522\end{array}$ & $\begin{array}{c}-0.023^{* * *} \\
(0.008) \\
16,520\end{array}$ & $\begin{array}{c}-0.0357^{* *} \\
(0.01453) \\
16,522\end{array}$ & $\begin{array}{c}-0.0245^{* * *} \\
(0.00583) \\
49,573\end{array}$ & $\begin{array}{c}-0.0873^{* * *} \\
(0.02661) \\
16,524\end{array}$ \\
\hline (4b) Terciles & & {$[0 ; 33.3]$} & & $(33.3 ; 66.6]$ & & $(66.6 ; 100]$ \\
\hline $\begin{array}{l}\text { coef. } \\
\text { sd } \\
\mathrm{N}\end{array}$ & & $\begin{array}{c}-0.0348^{* * *} \\
(0.00765) \\
27,542\end{array}$ & & $\begin{array}{c}-0.0174^{* * *} \\
(0.0059197) \\
27,542\end{array}$ & & $\begin{array}{c}-0.0641^{* * *} \\
(0.01841) \\
27,538\end{array}$ \\
\hline
\end{tabular}

Notes: ${ }^{*},{ }^{* *}$, and ${ }^{* * *}$ denote significance at the $10 \%, 5 \%$, and $1 \%$ levels. Dependent variable: meancentered, logarithmized rent/price of the apartment. Coefficients are estimated with the help of the within model (fixed effects). Standard errors (in parentheses) are robust to both arbitrary heteroscedasticity and intra-cluster correlation. 
tax rate is applied to some broader groups of apartments; these are divided into three different groups (terciles).

As the results show, OLS (within) regression substantially understates the income tax coefficient; the tax coefficient is too small in this specification. OLS regression seems to seriously bias the regression results. Therefore, we focus on specifications (2) to (4) in the following.

Regarding apartments for sale, the tax coefficients are significant for most price segments and model specifications. Capitalization seems to be very pronounced, especially in the low and top price segments. However, there is no clear tendency for the middle price segment. In some specifications, the tax coefficient is even insignificant. However, taking the three classes of the middle price segment together and forming a new class, including the $(20 ; 80]$ percentile, leads to strongly significant capitalization coefficients (in applying the tax rate for gross incomes of CHF 107'436). Nevertheless, the degree of capitalization seems to be lowest for the middle price segment. Relating on theory, it seems plausible that capitalization rates are higher for the low price segments compared to the middleprice apartments. Surprisingly, however, capitalization is substantially higher for the top price segment compared to the middle price segment.

There are several possible explanations for this phenomenon. First, the middle class is less mobile and less tax sensitive than the top income earners. Second, the top income earners may have an inelastic demand (in the sense that they mostly demand high-price apartments and do not want a lower quality apartment), which may lead to a segmented housing market with a different capitalization rate for each segment. Third, supply of luxury housing may be more inelastic compared to the supply of middle- and low-class housing (this is reasonable because attractive building sites, such as those with an exceptional view, are rare). All of these points may support the empirical result that capitalization is highest for the top price segment.

With respect to apartments for rent, capitalization is insignificant in most specifications for low-price apartments and for the top price segment. Only for the middle price segments do income taxes slightly capitalize into rental fees. An application of the Welch test (WeLCH, 1947) shows that the higher elasticity of apartments for sale compared to apartments for rent is statistically significant at the $0.1 \%$ level in all model specifications and for all three price segments, [0;20], $(20 ; 80]$, and $(80 ; 100]$. This signifies that property owners are more tax sensitive than renters during the search for a new apartment. This is rational because property owners cannot escape future tax burdens.

Irrespective of the chosen model specification, one obtains two robust results: First, capitalization is lower for apartments for rent compared to apartments for 
sale. Second, concerning apartments for sale, capitalization is well above $100 \%$ for the low and top price segments. In order to get a more comprehensive view of capitalization, we calculate an unweighted mean of the tax coefficients from models (2) to (4b) and then determine the implied capitalization rate with the help of Table 5. Results are summarized in Figure 2.

Figure 2: Degree of Capitalization

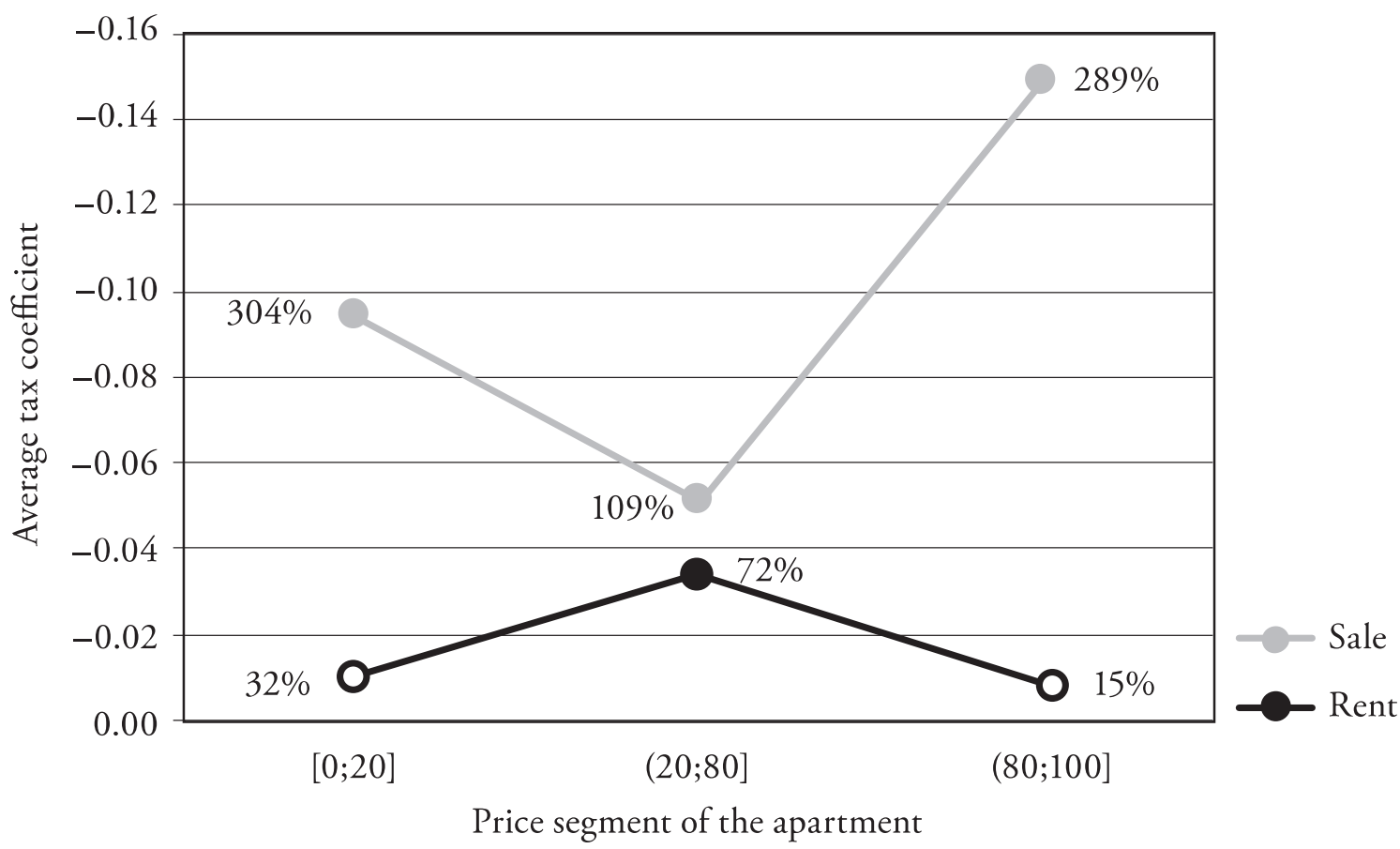

Notes: Inverted scale. Non-weighted average tax coefficients of models (2) to (4b). Non-filled dots: Tax coefficient is insignificant in all model specifications. Filled dots: Tax coefficient is significant in all model specifications. Data labels: Degree of income tax capitalization.

It is estimated that the degree of capitalization is around $100 \%$ for apartments for sale and $70 \%$ for apartments for rent in the broader middle price segment. Concerning the low and top price segments capitalization is about $300 \%$ for apartments for sale but insignificant for apartments for rent. Therefore, the results suggest that the process of capitalization is very complex, depending on the price segment of the apartment and whether the apartment is for sale or rent. 


\section{Conclusion}

With respect to income taxes, heterogeneity in capitalization should be prevalent. However, heterogeneity in income tax capitalization has not been explored empirically so far.

This study differs from previous works on income tax capitalization in that it estimates the capitalization rates for different apartment price segments. Estimations were performed by using a large dataset of advertised prices for more than 430,000 apartments across Switzerland between 2004 and 2010. The regression results support the hypothesis that capitalization varies substantially. Irrespective of the chosen model specification, one obtains two results that are relatively robust: First, capitalization is lower for apartments for rent compared to apartments for sale. Capitalization is insignificant or less than $100 \%$ for all rental segments. Second, concerning apartments for sale, capitalization is well above $100 \%$ for the low and top price segments.

Three main policy consequences can be driven by these results. First, regional tax competition can indeed lead to social segregation. Second, the segregation problem would mainly concern households that want to buy housing. Instead, renters are less likely affected as tax capitalization for rental objects seems to be moderate. Third, tax capitalization will cause geographical segregation not only between poor and rich home owners but also within affluent groups. People who are wealthy from an aggregate Swiss perspective (meaning that they belong to the top 20\%) may be "poor" in a regional comparison and could therefore be confronted with apartment prices in the top price segment that are not affordable to them in low-tax regions.

To sum up, results suggests that the process of capitalization is diverse, relating on the aspect to which price-segment the apartment belongs and whether apartments are for sale or for rent. Further research seems to be necessary in order to more deeply investigate the main drivers of heterogeneity in income tax capitalization.

\section{References}

Anglin, Paul M., and Ramazan Gençay (1996), "Semiparametric Estimation of a Hedonic Price Function”, Journal of Applied Econometrics, 11, pp. 633-648. Arellano, Manuel (1993), "On the Testing of Correlated Effects with Panel Data”, Journal of Econometrics, 59(1-2), pp. 87-97. 
Baum, Christopher F., Mark E. Schaffer, and Steven Stillmann (2007), "Enhanced Routines for Instrumental Variables / Generalized Method of Moments Estimation and Testing", Stata Journal, 7(4), pp. 465-506.

Boije, Robert (1997), "Capitalization, Efficiency and the Demand for Local Public Services", Economic Studies No.33, Department of Economics, Uppsala University.

Cameron, A. Colin, and Pravin T. Trivedi (2005), Microeconometrics: Methods and Applications, New York: Cambridge University Press.

Crampton, Graham (1996), "Local Government Structure and Urban Residential Location", Urban Studies, 33(7), pp. 1061-1076.

Dowding, Keith, Peter John, and Stephen Biggs (1994), "Tiebout: A Survey of the Empirical Literature", Urban Studies, 31(4-5), pp.767-797.

Edel, Matthew, and Elliott Sclar (1974), "Taxes, Spending, and Property Values: Supply Adjustment in a Tiebout-Oates Model”, Journal of Political Economy, 82(5), pp.941-954.

Epple, Dennis, and Thomas Romer (1989), "On Flexible Municipal Boundaries”, Journal of Urban Economics, 26(3), 307-319.

Ellickson, BRYAN (1971), "Jurisdictional Fragmentation and Residential Choice", American Economic Review, 61, 334-339.

Feld, Lars, and Gebhard Kirchgässner (1997), „Die Kapitalisierung von Steuern und öffentlichen Leistungen in den Mietzinsen: Eine empirische Überprüfung der Tiebout-Hypothese für die Schweiz", in Finanz- und Wirtschaftspolitik in Theorie und Praxis, Hans Schmid and Tilman Slembeck, eds., pp. 63-92, Berne: Haupt.

Feld, Lars, and Gebhard Kirchgässner (2001), "Income Tax Competition at the State and Local Level in Switzerland", Regional Science and Urban Economics, 31(2-3), pp. 181-213.

Feld, Lars, Justina A. V. Fischer, and Gebhard Kirchgässner (2010), “The Effect of Direct Democracy on Income Redistribution: Evidence for Switzerland", Economic Inquiry, 48(4), pp. 817-840.

Goodspeed, Timothy J. (1989), "A Re-Examination of the Use of Ability to Pay Taxes by Local Governments", Journal of Public Economics, 38(3), pp.319-342.

Greene, William H. (2008), Econometric Analysis, $6^{\text {th }}$ ed., Upper Saddle River, NJ: Prentice-Hall.

Halvorsen, Robert, and Henry O. Pollakowski (1981), "Choice of Functional Form for Hedonic Price Equations", Journal of Urban Economics, 10, pp. 37-47. 
Hilber, Christian A. (1998), Auswirkungen staatlicher Massnahmen auf die Bodenpreise. Eine theoretische und empirische Analyse der Kapitalisierung, Zurich: Verlag Rüegger.

Kirchgässner, Gebhard, and Werner W. Pommerehne (1996), “Tax Harmonization and Tax Competition in the European Union: Lessons from Switzerland", Journal of Public Economics, 60(3), pp. 351-371.

Liebig, Thomas, Patrick A. Puhani, and Alfonso Sousa-Poza (2007), "Taxation and Internal Migration - Evidence from the Swiss Census Using Community-Level Variation in Income Tax Rates", Journal of Regional Science, 47(4), pp. 807-836.

Morger, Mario (2013), "What Do Immigrants Value Most about Switzerland? Evidence of the Relative Importance of Income Taxes", CESifo Working Paper No. 4134.

Oates, Wallace E. (1969), "The Effects of Property Taxes and Local Public Spending on Property Values: An Empirical Study of Tax Capitalization and the Tiebout Hypothesis", Journal of Political Economy, 77(6), pp. 957-971.

Palmon, Oded, and Barton A. Smith (1998), "A New Approach for Identifying the Parameters of a Tax Capitalization Model", Journal of Urban Economics, 44(2), 299-316.

Rose-Ackermann, Susan (1983), "Beyond Tiebout: Modeling the Political Economy of Local Government", in Local Provision in Public Services: The Tiebout Model after Twenty-Five Years, George R. Zodrow, ed., pp. 55-83, New York: Academic Press.

Ross, Stephen, and John Yinger (1999), "Sorting and Voting: A Review of the Literature on Urban Public Finance, in Handbook of Regional and Urban Economics, Paul Cheshire and Edwin S. Mills, eds., chap.47, pp. 2001-2060, Amsterdam: Elsevier Science B.V.

Schmidheiny, Kurt (2006a), "Income Segregation from Local Income Taxation when Households Differ in both Preferences and Incomes", Regional Science and Urban Economics, 36(2), pp. 270-299.

Schmidheiny, Kurt (2006b), "Income Segregation and Local Progressive Taxation: Empirical Evidence from Switzerland", Journal of Public Economics, 90(3), pp. 429-458.

Sheppard, Stephen (1999), "Hedonic Analysis of Housing Markets", in Handbook of Regional and Urban Economics, Paul Cheshire and Edwin S. Mills, eds., chap. 41, pp. 1595-1635, Amsterdam: Elsevier Science B.V.

Sirmans, Stacy, Dean Gatzlaff, and David Macpherson (2008), "The History of Property Tax Capitalization in Real Estate", Journal of Real Estate Literature, 16(3), pp.327-343. 
Schaltegger, Christoph A., Frank Somogyi, and Jan-Egbert Sturm (2011), "Tax Competition and Income Sorting: Evidence from the Zurich Metropolitan Area", European Journal of Political Economy, 27(3), pp. 455-470.

Stadelmann, David (2010), "Which Factors Capitalize into House Prices? A Bayesian Averaging Approach”, Journal of Housing Economics, 19(3), pp. 180-204.

Stadelmann, David, and Steve Billon (2012), "Capitalization of Fiscal Variables and Land Scarcity”, Urban Studies, 49(7), pp. 1571-1594.

Stadelmann, David, and Steve Billon (2015), "Capitalization of Fiscal Variables Persists over Time”, Papers in Regional Science, 94(2), 347-363.

Stull, William J., and Judith C. Stull (1991), "Capitalization of Local Income Taxes”, Journal of Urban Economics, 29(2), pp. 182-190.

Tiebout, Charles M. (1956), "A Pure Theory of Local Expenditures", Journal of Political Economy, 64(5), pp. 416-424.

Welch, Bernard L. (1947), "The Generalization of 'Student's' Problem when Several Different Population Variances Are Involved”, Biometrika, 34 (1-2), pp. 28-35.

Westhoff, Frank (1977), "Existence of Equilibria in Economies with a Local Public Good", Journal of Economic Theory, 14(1), pp. 84-112.

Wooldridge, Jefreey M. (2002), Econometric Analysis of Cross Section and Panel Data, Cambridge, MA: MIT Press.

Yinger, John (1982), "Capitalization and the Theory of Local Public Finance", Journal of Political Economy, 90(5), pp. 917-943.

Yinger, John, Howard S. Bloom, Axel Börsch-Supan, and Helen F. Ladd (1988), Property Taxes and House Values: The Theory and Estimation of Intrajurisdictional Property Tax Capitalization, Boston: Academic Press. 